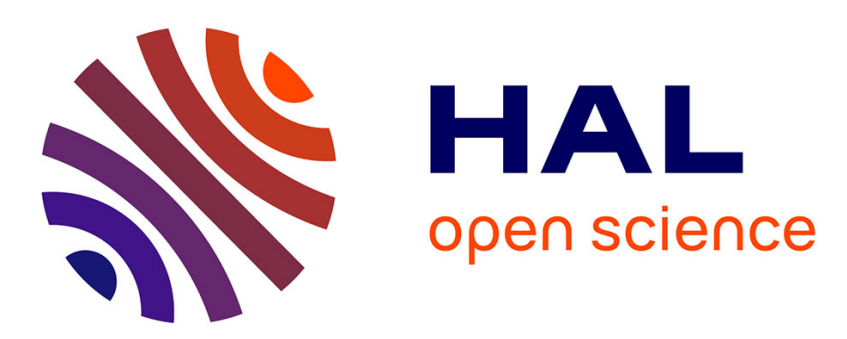

\title{
Seek and Find! PCR analyses of skin infections in West-European travelers returning from abroad with an eschar
}

\author{
Aurelie Morand, Emmanouil Angelakis, Mehdi Ben Chaabane, Philippe \\ Parola, Didier Raoult, Philippe Gautret
}

\section{To cite this version:}

Aurelie Morand, Emmanouil Angelakis, Mehdi Ben Chaabane, Philippe Parola, Didier Raoult, et al.. Seek and Find! PCR analyses of skin infections in West-European travelers returning from abroad with an eschar. Travel Medicine and Infectious Disease, 2018, 26, pp.32-36. 10.1016/j.tmaid.2018.02.009 . hal-01970229

\section{HAL Id: hal-01970229 \\ https://hal.science/hal-01970229}

Submitted on 10 Apr 2019

HAL is a multi-disciplinary open access archive for the deposit and dissemination of scientific research documents, whether they are published or not. The documents may come from teaching and research institutions in France or abroad, or from public or private research centers.
L'archive ouverte pluridisciplinaire HAL, est destinée au dépôt et à la diffusion de documents scientifiques de niveau recherche, publiés ou non, émanant des établissements d'enseignement et de recherche français ou étrangers, des laboratoires publics ou privés. 


\title{
Seek and Find! PCR analyses of skin infections in West-European travelers returning from abroad with an eschar
}

\author{
Aurélie Morand ${ }^{\mathrm{a}, \mathrm{b}}$, Emmanouil Angelakis ${ }^{\mathrm{a}}$, Mehdi Ben Chaabane ${ }^{\mathrm{a}}$, Philippe Parola ${ }^{\mathrm{c}}$, \\ Didier Raoult ${ }^{\mathrm{a}}$, Philippe Gautret ${ }^{\mathrm{c}, *}$ \\ a Aix Marseille Univ, IRD, AP-HM, MEPHI, IHU-Méditerranée Infection, Marseille, France \\ ${ }^{\mathrm{b}}$ Department of Pediatrics, Timone Hospital, AP-HM, Marseille, France \\ ${ }^{\mathrm{c}}$ Aix Marseille Univ, IRD, AP-HM, SSA, VITROME, IHU-Méditerranée Infection, Marseille, France
}

\section{A R T I C L E I N F O}

\section{Keywords:}

Skin biopsy

Cutaneous swab

Eschar

qPCR

Culture

\begin{abstract}
A B S T R A C T
Background: Skin infections are among the leading causes of diseases in travelers. Diagnosing pathogens could be difficult.

Method: We applied molecular assays for the diagnostic of a large collection of skin biopsies and swabs from travelers with suspected skin infections. All samples were tested by qPCR for Coxiella burnetti, Bartonella sp., Rickettsia sp., Borrelia sp., Ehrlichia sp., Tropheryma whipplei, Francisella tularensis, Mycobacteria sp., Staphylococcus aureus, Streptococcus pyogenes, Leishmania spp., Ortho poxvirus and Para poxvirus and then screened for the presence of bacteria by PCR amplification and sequencing, targeting the 16S rRNA gene.

Results: From January 2009 to January 2017, 100 international travelers presenting with a suspected skin infection were enrolled. We detected 51 patients with an identified pathogen on skin samples. Travelers presenting with eschars were more likely to have a positive PCR sample $(n=44 / 76,57.9 \%)$ compared to other patients ( $\mathrm{n}=7 / 24,29.2 \%)$. Spotted fever group Rickettsia $(\mathrm{n}=28)$ was the most frequently detected pathogens (19 R. africae, 6 R. conorii, $3 R$. mongolitimonae); S. aureus were detected in 11 patients; $S$. pyogenes in 3; Leishmania sp.; $M$. leprae and $B$. henselae in 1 patient, respectively.

Conclusion: By targeting the most commonly encountered causative agents of travel-related skin infections, our strategy provides a sensitive and rapid diagnostic method.
\end{abstract}

\section{Introduction}

Skin diseases are among the leading causes of health problems in travelers and are among the most common reasons for which travelers returning to France seek medical care [1,2]. Indeed, skin diseases are the third most common cause of health problems in travelers returning to France after febrile illnesses and acute diarrhoeas [3-5]. International travel has increased by $50 \%$ over the past decade and travelers are exposed to a variety of health risks in unfamiliar environments [6]. It is estimated that $10 \%$ of travel-related skin conditions may be serious enough to lead to hospitalization. Whereas most skin diseases have their clinical onset during travel, the remainder tend to occur in average 1 week after return [7]. Rickettsioses are caused by intracellular bacteria from the order Rickettsiales, and include dermatologic manifestations. These diseases, particularly tick-borne spotted fever group rickettsioses, have emerged in the field of travel medicine in recent years with increasing numbers of individuals being exposed to arthropod bites [6,8]. In a GeoSentinel study published in 2013, approximately 300 cases of travel-associated rickettsioses (with a majority of spotted fever group rickettsioses, $\mathrm{n}=267$ ) were reported for the 2007-2011time period, among more than 47,000 ill travelers returning to France [6]. In another study, Delord et al. reviewed approximatively 200 literature cases of travel-associated rickettsioses from 2004 to 2013, most cases were due to Rickettsia africae $(\mathrm{n}=106)$ and Rickettsia typhi $(\mathrm{n}=51)$ [8]. As a reference center for rickettsioses, our laboratory receives regularly skin biopsies or swabs obtained from patients with dermatological problems and/or suspicion of rickettsioses. In this study, we applied prospectively molecular assays for the detection of a panel of bacterial, viral and parasitic agents in a large collection of skin biopsies and/or swabs from travelers with suspected skin infections.

\footnotetext{
* Corresponding author. IHU-Méditerranée-Infection, 19-21 Boulevard Jean Moulin, 13005 Marseille, France.

E-mail address: philippe.gautret@ap-hm.fr (P. Gautret).
} 


\section{Method}

\subsection{Ethic}

The study was approved by the ethic comity of the IHU Méditerranée-Infection under the name "Detection of microorganisms in biological samples received in the national reference center for Rickettsioses", number 2016_025. All samples were anonymized.

\subsection{Samples}

We analyzed skin biopsies and/or cutaneous swabs of skin lesions from travelers with suspected skin infections that were sent to our laboratory (national reference center for Rickettsioses) from January 2009 to January 2017. Clinical data, medical history, tick bite, animal contact, date and country of exposure and ongoing antibiotic treatment were documented by physicians thanks to letters, emails, phone calls or specific medical surveys. The specimens sent to our reference center were obtained from hospitalized patients and outpatients throughout France and West Europe. Skin swabs were collected by rotating a dry sterile cotton swab into the lesion whereas skin biopsies were performed by trained practitioners, after local anesthesia and in sterile conditions. The swabs and skin biopsies were transported to the laboratory, with or without specific media, frozen, at $4{ }^{\circ} \mathrm{C}$ or at ambient temperature.

\subsection{Molecular assays}

The total genomic DNA was extracted from samples using a QIAamp tissue kit (Qiagen, Hilden, Germany). The samples were handled under sterile conditions to avoid cross-contamination. The genomic DNA was stored at $4{ }^{\circ} \mathrm{C}$ and used as a template in the qPCR assays. All samples were tested by qPCR for the presence of Coxiella burnetti, Bartonella sp., Rickettsia sp., Borrelia sp., Ehrlichia sp., Tropheryma whipplei, Francisella tularensis, Mycobacteria sp., Staphylococcus aureus, Streptococcus pyogenes, Leishmania sp., Ortho poxvirus and Para poxvirus by primers and probes as previously described [9]. For the second qPCR assay, in order to characterize the species level of Bartonella sp., Rickettsia sp., Borrelia sp. or Mycobacteria sp., we used primers and probes as previously described $[9,10]$. Samples from travelers returning from the Asian Pacific region were moreover tested for Orientia tsutsugamushi as previously described [11]. All samples were systematically screened for the presence of bacteria by PCR amplification and sequencing, targeting the 16S rRNA gene as previously described [9]. The quality of DNA extraction was assessed by the incorporation of a housekeeping gene encoding beta-actin to samples [9]. In case of $S$. aureus positive skin sample, mecA gene was searched as previously described in order to detect methicillin-resistant $S$. aureus [12].

\subsection{Case definition}

Patients were classified as definitely infected if a molecular assay was positive.

\subsection{Statistical analyses}

We compared sampling method performance (skin swabs and skin biopsies) using Fisher $\chi^{2}$ analysis with Epi Info software $(\mathrm{p}<0.05)$.

\section{Results}

\subsection{Patients}

A total of 100 international travelers presenting with a suspected skin infection were enrolled (Fig. 1). The mean age of patients was 47.2 years (ranging from 6 to 79 years), $57(57.0 \%)$ were males and 43
(43.0\%) were females.

The samples were sent from 52 different centers (supplementary data).

One hundred and five places of exposure were identified as 5 patients traveled in more than one place and had multiple exposures: Africa ( $\mathrm{n}=60 / 105,57.1 \%)$, Asia ( $\mathrm{n}=23 / 105,21.9 \%)$, South America $(\mathrm{n}=11 / 105,10.5 \%)$, Europe $(\mathrm{n}=8 / 105,7.6 \%)$, Australia $(\mathrm{n}=2$ ) $105,1.9 \%)$ and Polynesia $(\mathrm{n}=1 / 105,1.0 \%)$.

Most patients presented several different non-specific symptoms (Fig. 1).

A total of $76 / 100(76 \%)$ patients presented with eschars, 54/76 (71.1\%) had one eschar, 21/76 (27.6\%) had several eschars, 14/76 patients had eschars on the trunk, $11 / 76$ on the upper limbs, $29 / 76$ on the lower limbs, $10 / 76$ on the head and/or neck and $4 / 76$ on the perineal area. Among those patients with eschars, 37/76 (48.7\%) patients had a skin rash, 36/37 (97.3\%) of them had maculo-papular rash and $1(2.7 \%)$ had vesicular rash; 46/76 (60.5\%) suffered from fever; $19 / 76(25.0 \%)$ had lymph node enlargement, 16/19 (84.2\%) had a unique lymphatic drainage area involvement, 3/19 (15.8\%) had multiple lymphatic drainage area involvement, axillary area was involved in $4 / 19$ cases $(21.1 \%)$, inguinal in $10 / 19$ cases $(52.6 \%)$, cervical in $6 /$ 19 cases (31.6\%) and trunk in 2/19 cases (10.5\%); 27/76 (35.5\%) patients mentioned a tick bite and 5/76 (6.6\%) patients presented a scalp eschar associated with neck lymphadenopathy following a tick bite (SENLAT). Other symptoms were reported, 5/76 (6.6\%) cases suffered from headaches, $1 / 76$ cases from myalgia $(1.3 \%), 1 / 76$ cases from poly-arthralgia (1.3\%), 1/76 cases from diarrhea (1.3\%), 1/76 cases from retinopathy $(1.3 \%), 2 / 76(2.6 \%)$ cases from neurological symptoms, $1 / 76$ (1.3\%) cases from respiratory distress syndrome, $2 / 76$ (2.6\%) cases from renal failure, $1 / 76$ cases from cytopenia (1.3\%), 1/76 $(1.3 \%)$ cases from hepatitis cytolysis and $1 / 76$ (1.3\%) patients died.

The 24/100 (24.0\%) patients without eschars had skin rash in 24/ 24 (100.0\%) cases, all maculo-papular; $2 / 24$ (8.3\%) lymph nodes, with a unique area concerned, $1 / 2(50.0 \%)$ axillary, $1 / 2(50.0 \%)$ inguinal; $16 / 24(66.7 \%)$ had fever; $1 / 24(4.2 \%)$ had headache and $1 / 24(4.2 \%)$ had neurological troubles.

A total of 55/100 (55\%) patients had already received a probabilistic antibiotic treatment when the skin biopsy was sampled, among them, 48/55 (87.3\%) had received a monotherapy and 7/55 (12.7\%) more than one antibiotic therapy, including 47/55 (85.5\%) patients treated with doxycycline, 1/55 with amoxicillin, 4 with amoxicillin and clavulanate, 4 with pristinamycin, 2 with azithromycin, 1 with fucidic acid, 1 with imipenem, 1 with amikacin, 1 with metronidazole, 1 with amoxicillin, 1 with ceftazidime and 1 with teicoplanin. One additional patient was treated with itraconazole at the time of sampling. Regarding the 51 patients for whom a pathogen identification was obtained in our lab, the probabilistic antibiotic treatment given previously to the results was adapted in 27 cases (52.9\%).

\subsection{Diagnoses}

All patients underwent skin biopsy and/or skin swab, totalizing 83 skin biopsies and 28 skin swabs (111 skin samples) and 11 patients provided both. Fifty-one (51\%) patients had one or more identified pathogens diagnosed on each skin sample (Fig. 1). We identified pathogens in 42/83 (50.6\%) skin biopsies and detected 13/28 (46.4\%) positive skin swabs, no significative difference in positive results was observed when comparing skin biopsies and skin swabs $(\mathrm{OR}=1.2$ [0.5-3.1]; $\mathrm{p}=0.8$ ). Most of the positive diagnostics were performed thanks to qPCR ( $\mathrm{n}=50 / 51 ; 98.0 \%$ ); only $716 \mathrm{~S}$ RNA PCR were positive (1 poly-microbial, 1 Streptococcus pyogenes, 4 Staphylococcus aureus and a new bacterial species which wasn't found by qPCR). Travelers presenting with eschars were more likely to have a positive PCR sample for an infectious agent $(n=44 / 76,57.9 \%)$ compared to other patients ( $\mathrm{n}=7 / 24,29.2 \%$ ).

Spotted fever group (SFG) Rickettsia $(n=28)$ were the most 


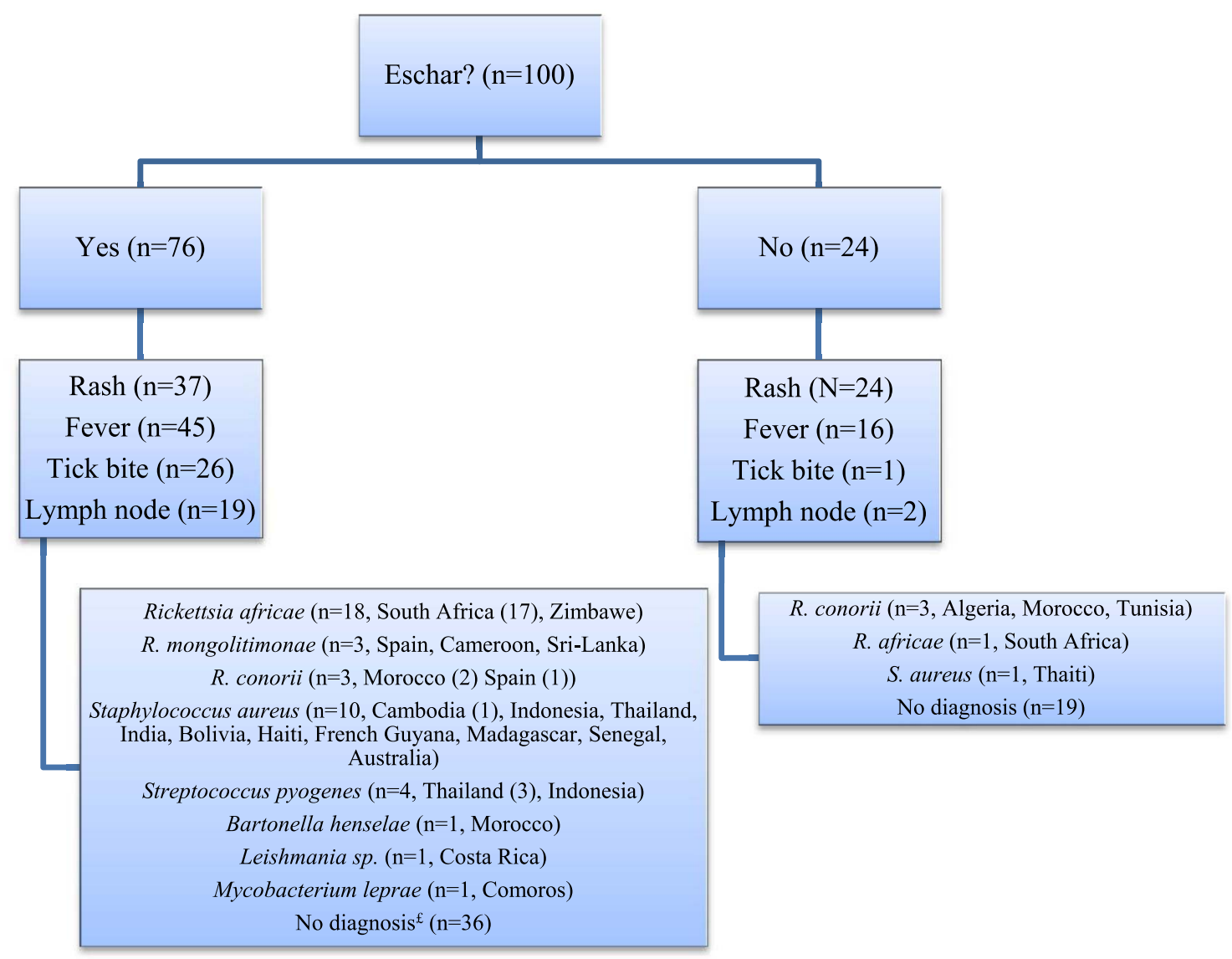

Fig. 1. Clinical presentation and microbiological results of 100 international travelers with suspected skin infection.

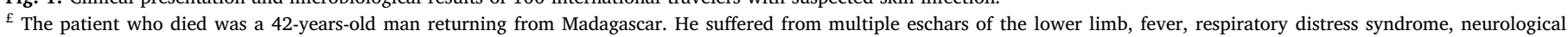

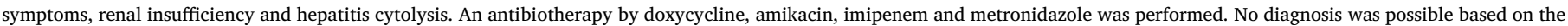
analysis of skin biopsy specimens.

frequently isolated pathogens with $R$. africae exclusively found in patients returning from South Africa $(\mathrm{n}=18)$ and Zimbabwe $(\mathrm{n}=1) . R$. conorii $(n=6)$ was diagnosed in travelers returning from Spain $(n=1)$ and from North Africa including Algeria $(\mathrm{n}=1)$, Tunisia $(\mathrm{n}=1)$ and Morocco $(\mathrm{n}=3)$. $R$. mongolitimonae $(\mathrm{n}=3)$ was found in travelers returning from Spain $(n=1)$, Cameroon $(n=1)$ and Sri-Lanka $(n=1)$.

$S$. aureus was the second most common agent of skin infection in travelers returning to France $(\mathrm{n}=11)$. $S$. aureus cases were diagnosed in travelers from various regions, Guyana $(n=1)$, Tahiti $(n=1)$, Cambodia $(n=1)$, Indonesia $(n=1)$, Haiti $(n=1)$, India $(n=1)$, Madagascar $(n=1)$, Senegal $(n=1)$, Thailand $(n=1)$, Australia $(\mathrm{n}=1)$ and Bolivia $(\mathrm{n}=1)$ (Fig. 1). No MecA gene was amplified from the 7 samples that were tested for.

$S$. pyogenes $(\mathrm{n}=4)$ was detected in travelers returning from Thailand $(\mathrm{n}=3)$ and Indonesia $(\mathrm{n}=1)$.

Leishmania sp. was found in a patient who had traveled to Costa Rica and $M$. leprae in a patient returning from Comoros. Finally, B. henselae was the cause of cutaneous symptoms in a traveler returning from Morocco.

\section{Discussion}

In this comprehensive study, we used molecular assays on skin biopsies and swabs for the diagnosis of skin infection in travelers. The diagnosis of skin infection is considered difficult because symptoms are usually non-specific and because there is no standardized laboratory procedure for the diagnostic of skin infections. Identification of the pathogen could be performed thanks to serology (but this method isn't performing in the 2 or 3 weeks following contamination), culture of blood or skin lesion biopsy or swab (but this method is fastidious, timeconsuming, slow and requires culture media transport) and/or molecular essay on blood or skin lesion biopsy or swab. Using skin swabs is a validated method and easier to perform than skin biopsy. Eschar swabbing by rotating into the lesion with a dry sterile cotton swab is non-invasive, non-painful and could be performed by every medical staff, especially in field conditions, whereas skin biopsy need to be performed by trained practitioners, after local anesthesia and in sterile conditions. The swab could be easily transported in 3 days to the laboratory, without specific media, with an optimal storage at $4{ }^{\circ} \mathrm{C}$ $[13,14]$. Our strategy is based on qPCR targeting the most frequent causative agents known to be responsible for skin infections in international travelers. Moreover, the use of $16 \mathrm{~S}$ rDNA PCR is critical in order to identify new or emerging bacterial agents. A limitation of our study was that samples were not systematically tested for fungi. Moreover, samples were analyzed for only Para poxvirus and Ortho poxvirus and not for other viruses that may also account for skin infections.

The high frequency of rickettsial diseases in our series may reflect the emergence of $R$. africae in recent years in southern Africa, as reported in several single-site studies [3,4]. However, these results should be interpreted with caution, since our laboratory is a reference center for $\mathrm{Q}$ fever, rickettsioses, and Bartonella infections, which likely partially accounts for the very high percentage of positive SFG rickettsioses in our study due to an over-representation of specimens from patients with suspected rickettsioses, based on clinical and epidemiological criteria. We diagnosed $R$. conorii among travelers from the Mediterranean area only, confirming that the majority of individuals with Mediterranean spotted fever were infected in this area [15]. On the 
contrary, $R$. mongolitimonae had no specific geographical repartition in our study (Asia, Europe, Africa), which corroborates literature data [13]. We found that $S$. aureus was the second more frequent cause of skin infections in our series with no specific geographical pattern. It was previously reported that $S$. aureus was responsible for $8-18 \%$ of all skin diseases in travelers returning from abroad without specific geographical repartition [16]. No mecA resistance genes were found in our survey which does not corroborate results obtained in patients living in or returning from developing countries and suffering skin infections [16-19]. This could result from the small effective of $S$. aureus skin infections in our study. S. pyogenes was exclusively detected in patients returning from Asia in our study, and yet this disease is ubiquitous though more represented in developing countries [20]. We found 1 cutaneous leishmaniasis in a patient infected in Costa Rica where this disease is known to be endemic throughout Latin America [21]. Cutaneous leishmaniasis is an emerging diseases in European travelers with most cases acquired in Latin America and the Middle East [22]. Influx of immigrants and military operations are among other potential reasons for this emergence among international travelers [23]. One $M y$ cobacterium leprae infection was acquired in the Comoros. A French study conducted from 2009 to 2013 reported that the Comoros were the main focus of Mycobacterium leprae infections diagnosed in France [24], while in a study conducted in Madrid, from 1989 to 2015, most cases were migrants from South America [25] and in a Danish study conducted from 1980 to 2010, most cases were migrants from South-East Asia [26]. In our study, one Bartonella henselae case was diagnosed in a patient returning from Morocco, a disease rarely described in Morocco [27-30], while fleas have been shown to be positive for Bartonella henselae in this country [31].

Among the 51 patients for whom a pathogen was identified in skin samples, the probabilistic antibiotic treatment introduced by the sending center previously to the results were adapted in half cases. Unfortunately, we don't have the data about the secondary outcome of the patient after centers received our results.

In conclusion, the diagnosis of travel-related skin infections is particularly challenging because of a broad differential diagnostic strategies and the physicians' unfamiliarity with rare diseases [32-34]. Our strategy, by targeting the most commonly encountered causative agents, provides a sensitive and rapid diagnostic method in this context.

\section{Conflicts of interest}

None.

\section{Funding sources}

None.

\section{Appendix A. Supplementary data}

Supplementary data related to this article can be found at http://dx. doi.org/10.1016/j.tmaid.2018.02.009.

\section{References}

[1] Caumes E, Legros F, Duhot D, Cohen J-M, Arnould P, Mosnier A. Health problems in returning travelers consulting general practitioners. J Trav Med 2008;15:457-9. http://dx.doi.org/10.1111/j.1708-8305.2008.00246.x.

[2] Gautret P, Cramer JP, Field V, Caumes E, Jensenius M, Gkrania-Klotsas E, et al. Infectious diseases among travellers and migrants in Europe, EuroTravNet 2010. Euro Surveill Bull Eur Sur Mal Transm Eur Commun Dis Bull 2012:17.

[3] Herbinger K-H, Siess C, Nothdurft HD, von Sonnenburg F, Löscher T. Skin disorders among travellers returning from tropical and non-tropical countries consulting a travel medicine clinic. Trop Med Int Health TM IH 2011;16:1457-64. http://dx.doi. org /10.1111/j.1365-3156.2011.02840.x.

[4] Freedman DO, Weld LH, Kozarsky PE, Fisk T, Robins R, von Sonnenburg F, et al. Spectrum of disease and relation to place of exposure among ill returned travelers. N Engl J Med 2006;354:119-30. http://dx.doi.org/10.1056/NEJMoa051331.

[5] Field V, Gautret P, Schlagenhauf P, Burchard G-D, Caumes E, Jensenius M, et al.
Travel and migration associated infectious diseases morbidity in Europe. BMC Infect Dis 2008;2010(10):330. http://dx.doi.org/10.1186/1471-2334-10-330.

[6] Leder K, Torresi J, Libman MD, Cramer JP, Castelli F, Schlagenhauf P, et al. GeoSentinel surveillance of illness in returned travelers, 2007-2011. Ann Intern Med 2013;158:456-68. http://dx.doi.org/10.7326/0003-4819-158-6-201303190 00005.

[7] Caumes E, Carrière J, Guermonprez G, Bricaire F, Danis M, Gentilini M. Dermatoses associated with travel to tropical countries: a prospective study of the diagnosis and management of 269 patients presenting to a tropical disease unit. Clin Infect Dis Off Publ Infect Dis Soc Am 1995;20:542-8.

[8] Delord M, Socolovschi C, Parola P. Rickettsioses and Q fever in travelers. Trav Med Infect Dis 2004-2013;2014(12):443-58. http://dx.doi.org/10.1016/j.tmaid.2014 08.006.

[9] Safont M, Angelakis E, Richet H, Lepidi H, Fournier P-E, Drancourt M, et al. Bacterial lymphadenitis at a major referral hospital in France from 2008 to 2012. J Clin Microbiol 2014;52:1161-7. http://dx.doi.org/10.1128/JCM.03491-13.

[10] Bruijnesteijn Van Coppenraet ES, Lindeboom JA, Prins JM, Peeters MF, Claas ECJ, Kuijper EJ. Real-time PCR assay using fine-needle aspirates and tissue biopsy specimens for rapid diagnosis of mycobacterial lymphadenitis in children. J Clin Microbiol 2004;42:2644-50. http://dx.doi.org/10.1128/JCM.42.6.2644-2650. 2004.

[11] Angelakis E, Patrick G, Peloni JM, Wey PF, Perreal C, Raoult D. Orientia tsutsugamushi in lung of patient with acute respiratory distress syndrome, France. Emerg Infect Dis 2013;2015(21):373-5. http://dx.doi.org/10.3201/eid2102.140860.

[12] Rolain J-M, François P, Hernandez D, Bittar F, Richet H, Fournous G, et al. Genomic analysis of an emerging multiresistant Staphylococcus aureusstrain rapidly spreading in cystic fibrosis patients revealed the presence of an antibiotic inducible bacteriophage. Biol Direct 2009;4:1. http://dx.doi.org/10.1186/1745-6150-4-1.

[13] Parola P, Paddock CD, Socolovschi C, Labruna MB, Mediannikov O, Kernif T, et al Update on tick-borne rickettsioses around the world: a geographic approach. Clin Microbiol Rev 2013;26:657-702. http://dx.doi.org/10.1128/CMR.00032-13.

[14] Socolovschi C, Renvoisé A, Brouqui P, Parola P, Raoult D. The use of eschar swabs for the diagnosis of African tick-bite fever. Ticks Tick-Borne Dis 2012;3:361-3. http://dx.doi.org/10.1016/j.ttbdis.2012.10.018.

[15] Jensenius M, Fournier P-E, Raoult D. Rickettsioses and the international traveler. Clin Infect Dis Off Publ Infect Dis Soc Am 2004;39:1493-9. http://dx.doi.org/10. $1086 / 425365$.

[16] Zanger P. Staphylococcus aureus positive skin infections and international travel. Wien Klin Wochenschr 2010;122(Suppl 1):31-3. http://dx.doi.org/10.1007/ s00508-010-1333-1.

[17] Bonesso MF, Marques SA, Camargo CH, Fortaleza CMCB, da Cunha M de LR de S. Community-associated methicillin-resistant Staphylococcus aureus in non-outbreak skin infections. Braz J Microbiol 2015;45:1401-7.

[18] Nurjadi D, Friedrich-Jänicke B, Schäfer J, Van Genderen PJJ, Goorhuis A, Perignon A, et al. Skin and soft tissue infections in intercontinental travellers and the import of multi-resistant Staphylococcus aureus to Europe. Clin Microbiol Infect 2015;21:567. http://dx.doi.org/10.1016/j.cmi.2015.01.016. e1-567.e10.

[19] Maina EK, Kiiyukia C, Wamae CN, Waiyaki PG, Kariuki S. Characterization of methicillin-resistant Staphylococcus aureus from skin and soft tissue infections in patients in Nairobi, Kenya. Int J Infect Dis 2013;17:e115-9. http://dx.doi.org/10. 1016/j.ijid.2012.09.006.

[20] Efstratiou A, Lamagni T. Epidemiology of Streptococcus pyogenes. In: Ferretti JJ, Stevens DL, Fischetti VA, editors. Streptococcus pyogenes basic biol. Clin. Manif. Oklahoma City (OK): University of Oklahoma Health Sciences Center; 2016.

[21] Alvar J, Vélez ID, Bern C, Herrero M, Desjeux P, Cano J, et al. Leishmaniasis worldwide and global estimates of its incidence. PLoS One 2012;7:e35671. http:// dx.doi.org/10.1371/journal.pone.0035671.

[22] Gautret P, Schlagenhauf P, Gaudart J, Castelli F, Brouqui P, von Sonnenburg F, et al Multicenter EuroTravNet/GeoSentinel study of travel-related infectious diseases in Europe. Emerg Infect Dis 2009;15:1783-90. http://dx.doi.org/10.3201/eid1511. 091147.

[23] Mansueto P, Seidita A, Vitale G, Cascio A. Leishmaniasis in travelers: a literature review. Trav Med Infect Dis 2014;12:563-81. http://dx.doi.org/10.1016/j.tmaid. 2014.09.007.

[24] Reibel F, Chauffour A, Brossier F, Jarlier V, Cambau E, Aubry A. New insights into the geographic distribution of Mycobacterium leprae SNP genotypes determined for isolates from leprosy cases diagnosed in metropolitan France and French territories. PLoS Neglected Trop Dis 2015;9. http://dx.doi.org/10.1371/journal.pntd. 0004141.

[25] Norman FF, Fanciulli C, Pérez-Molina J-A, Monge-Maillo B, López-Vélez R. Imported and autochthonous leprosy presenting in Madrid (1989-2015): A case series and review of the literature. Trav Med Infect Dis 2016;14:331-49. http://dx doi.org/10.1016/j.tmaid.2016.06.008.

[26] Aftab H, Nielsen SD, Bygbjerg IC. Leprosy in Denmark 1980-2010: a review of 15 cases. BMC Res Notes 2016;9:10. http://dx.doi.org/10.1186/s13104-015-1768-6.

[27] Zekraoui Y, Megzari A, El Alloussi T, Berraho A. Unilateral neuroretinitis revealing cat-scratch disease. Rev Med Interne 2011;32:e46-8. http://dx.doi.org/10.1016/j. revmed.2010.02.016.

[28] Derrar R, Daoudi R. Stellar neuroretinitis revealing bartonellosis. Pan Afr Med J 2014;19:344. http://dx.doi.org/10.11604/pamj.2014.19.344.4017.

[29] Lezrek O, Laghmari M, Jait A, El Atiqi A, Lezrek M, Daoudi R. Neuroretinitis in ocular bartonellosis. J Pediatr 2015;166. http://dx.doi.org/10.1016/j.jpeds.2014. 10.022. 496-496.e1.

[30] Nkaoui M, El Bardouni A, Lazrek O, Ibo N, Zouaidia F, Kharmaz M, et al. Elbow abscess revealing cat-scratch disease: about a case. Pan Afr Med J 2017;27:67. http://dx.doi.org/10.11604/pamj.2017.27.67.12427. 
[31] Boudebouch N, Sarih M, Beaucournu J-C, Amarouch H, Hassar M, Raoult D, et al. Bartonella clarridgeiae, B. henselae and Rickettsia felis in fleas from Morocco. Ann Trop Med Parasitol 2011;105:493-8. http://dx.doi.org/10.1179/1364859411Y. 0000000038.

[32] Dzelalija B, Punda-Polic V, Medic A, Dobec M. Rickettsiae and rickettsial diseases in Croatia: implications for travel medicine. Trav Med Infect Dis 2016 Sep Oct;14(5):436-43. http://dx.doi.org/10.1016/j.tmaid.2016.06.010.

[33] Leblebicioglu H, Ozaras R, Fletcher TE, Beeching NJ. ESCMID study group for infections in travellers and migrants (ESGITM).Crimean-Congo haemorrhagic fever in travellers: a systematic review. Trav Med Infect Dis 2016 Mar-Apr;14(2):73-80. http://dx.doi.org/10.1016/j.tmaid.2016.03.002.

[34] Dreshaj S, Ahmeti S, Ramadani N, Dreshaj G, Humolli I, Dedushaj I. Current situation of Crimean-Congo hemorrhagic fever in Southeastern Europe and neighboring countries: a public health risk for the European Union? Trav Med Infect Dis 2016 Mar-Apr;14(2):81-91. http://dx.doi.org/10.1016/j.tmaid.2016.03.012. 